\title{
Glucose plus metformin compared with glucose alone on $\beta$-cell function in mouse pancreatic islets
}

\author{
MAHMOUD HASHEMITABAR, SOMAYEH BAHRAMZADEH, \\ SADEGH SAREMY and FRESHTEH NEJADDEHBASHI
}

\begin{abstract}
Cellular and Molecular Research Center, Faculty of Medicine, Ahvaz Jundishapur University of Medical Sciences, Ahvaz, Khuzestan 61357-15794, Iran
\end{abstract}

Received March 5, 2015; Accepted April 24, 2015

DOI: $10.3892 /$ br.2015.476

\begin{abstract}
Metformin is currently the first drug of choice for treatment of type II diabetes. The primary function of metformin is to decrease hepatic glucose production mainly by inhibiting gluconeogenesis. The aim of the present study was to investigate the effects of glucose alone (control groups) and glucose and metformin (treatment groups) on pancreatic islets functions. Pancreatic islets were isolated by collagenase digestion and incubated for 24 or $48 \mathrm{~h}$ in RPMI-1640 containing $5 \mathrm{mmol} / \mathrm{l}$ glucose (control groups 1 and 2, respectively) or $24 \mathrm{~h}$ with $25 \mathrm{mmol} / \mathrm{l}$ glucose (control group 3) and $15 \mu \mathrm{mol} / \mathrm{l}$ metformin (treatment groups 1,2 and 3, corresponding to the control groups, respectively). Subsequently, the rate of insulin output from islets, pancreatic and duodenal homeobox $1(P d x-1)$ and insulin genes expression and islet viability were assayed. The rate of insulin secretion in a $5 \mathrm{mmol} / \mathrm{l}$ glucose concentration in the $48 \mathrm{~h}$ treatment group increased significantly compared with that of the $24 \mathrm{~h}$ treatment group $(\mathrm{P}<0.05)$. An increase of the glucose concentration $(25 \mathrm{mmol} / \mathrm{l})$ caused insulin secretion to increase compared with that of $5 \mathrm{mmol} / 1$ glucose. $P d x-1$ gene expression in treatment group 2 significantly decreased compared with the control group $2(\mathrm{P}<0.05)$. The the $P d x-1$ gene expression in treatment group 2 decreased compared with that of the treatment group 1. The expression of the insulin gene in treatment group 1 increased compared with control group 1, and in treatment group 2, there was a 2-fold increase in insulin gene expression compared with control group 2. The insulin gene expression in treatment group 2 increased compared with treatment group 1. The percentage of islet cell viability was increased in treatment group 3 by $\sim 40 \%$ compared with the islet cells of treatment groups 1 and $2(\mathrm{P}<0 / 05)$. These data indicate that glucose and metformin have direct effects on $\beta$-cell function.
\end{abstract}

Correspondence to: Ms. Somayeh Bahramzadeh, Cellular and Molecular Research Center, Faculty of Medicine, Ahvaz Jundishapur University of Medical Sciences, Ahvaz, Khuzestan 61357-15794, Iran E-mail: bahramzade2007@gmail.com

Key words: glucose, metformin, pancreatic islets function

\section{Introduction}

Diabetes mellitus is a disease affecting 5\% of people worldwide. Type I diabetes is mainly due to autoimmune damage of pancreatic $\beta$-cells and patients are dependent on exogenous insulin, and this accounts for $5-10 \%$ of all the diabetic cases. Type II diabetes develops more slowly and the intensity of metabolic disturbances is much lower and accounts for $90-95 \%$ of all diabetic cases $(1,2)$. In type II diabetes, the reduction in $\beta$-cell mass and insulin secretion was observed (3-5).

Metformin is the first choice for the treatment of type II diabetes. In type II diabetes, metformin lowers blood glucose concentrations without causing overt hypoglycemia, and therefore is an antihyperglycemic agent. Metformin is also described as an insulin-sensitizer causing reduction in insulin resistance and the plasma fasting insulin level. The positive effects of metformin on insulin receptor expression and tyrosine kinase activity could be improving the insulin sensitivity $(6,7)$. However, the primary function of metformin is to decrease hepatic glucose production $(8)$, mainly by inhibiting gluconeogenesis $(9,10)$.

Studies on the rat pancreas (11) and isolated human islets (12) have shown that metformin improved insulin release in response to glucose. A previous study has demonstrated that metformin can restore the normal secretory pattern in isolated rat islets that were incubated in the presence of elevated glucose or free fatty acid concentrations (13).

In the adult pancreas, pancreatic and duodenal homeobox 1 $(\mathrm{Pdx}-1)$ regulates the genes associated with pancreatic cell differentiation and maturation, which includes the glucose transporter 2, insulin, glucokinase and amyloid precursor protein genes (14). The decision to test metformin was based on these considerations and the results showed that the drug can reverse the majority of the alterations found in type II diabetes islets.

The aim of the present study was to investigate the direct effects of metformin on pancreatic $\beta$-cells by incubation of pancreatic islets cells undergoing glucose stress to assess the expression of $P d x-1$ and insulin genes, $\beta$-cell function and viability.

\section{Materials and methods}

Animals. A total of 56 male NMRI mice (25-30 g) (9 mice in each group) were obtained from the Animal House of Ahvaz 
Table I. Sequence information on the primers used for qPCR.

\begin{tabular}{|c|c|c|c|}
\hline Gene & Sequences $\left(5^{\prime} \rightarrow 3^{\prime}\right)$ & Product size, bp & Gene ID \\
\hline$P d x-1$ & $\begin{array}{l}\text { F: CCGAGAGACACATCAAAATCTGG } \\
\text { R: CCCGCTACTACGTTTCTTATCTTCC }\end{array}$ & 80 & NM_008814.3 \\
\hline Insulin & $\begin{array}{l}\text { F: AGGACCCACAAGTGGCACA } \\
\text { R: GAGGGGTAGGCTGGGTAGTG }\end{array}$ & 184 & NM_001185084.1 \\
\hline Glut-2 & $\begin{array}{l}\text { F: TTGACTGGAGCCCTCTTGATG } \\
\text { R: CACTTCGTCCAGCAATGATGA }\end{array}$ & 73 & NM_031197.2 \\
\hline$\beta$-actin & $\begin{array}{l}\text { F: GGCCAACCGTGAAAAGATGA } \\
\text { R: CACAGCCTGGATGGCTACGT }\end{array}$ & 79 & NM_007393.3 \\
\hline
\end{tabular}

qPCR, quantitative polymerase chain reaction; bp, base pairs; F, forward; R, reverse.

Jundishapur University of Medical Sciences (Ahvaz, Iran), The mice were housed in cages $\left(22 \pm 2^{\circ} \mathrm{C}\right.$, under a standard 12-h light:12-h dark cycle) and allowed ad libitum feed access. All the experimental protocols were performed according to the Standards for Animal Care, and they were approved by the Ethics Committee of Ahvaz Jundishapur University of Medical Sciences.

Isolation of mice pancreatic islets. Pancreatic islets were isolated from overnight-fasted male NMRI mice by the Lacy and Kostianovsky-modified collagenase digestion method (13). In brief, following cervical dislocation, the abdomen of the animals was opened. The common bile duct was occluded at the distal end, close to the duodenum. Hanks' balanced salt solution (HBSS; $5 \mathrm{ml}$ ) [115 mmol/1 $\mathrm{NaCl}, 10 \mathrm{mmol} / 1 \mathrm{NaHCO}_{3}, 5 \mathrm{mmol} / \mathrm{l} \mathrm{KCl}, 1.1 \mathrm{mmol} / 1 \mathrm{MgCl}_{2}$, $1.2 \mathrm{mmol} / 1 \mathrm{NaH}_{2} \mathrm{PO}_{4}, 2.5 \mathrm{mmol} / 1 \mathrm{CaCl}_{2}, 25 \mathrm{mmol} / 1 \mathrm{HEPES}$

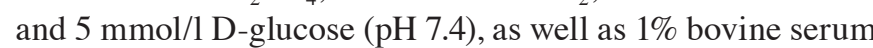
albumin (Merck KGaA, Darmstadt, Germany)] containing $1.4 \mathrm{mg} / \mathrm{ml}$ of collagenase IV (Sigma, St. Louis, MO, USA) was injected into the duct $(14,15)$.

After removal of the pancreas, it was placed into a $50 \mathrm{ml}$ conical tube and incubated for $15 \mathrm{~min}$ in a $37^{\circ} \mathrm{C}$ water bath. Subsequently, $15 \mathrm{ml}$ of cold HBSS was added to the tube to dilute the collagenase concentration and stop a further digestion process. For washing the collagenase from the islet tissues, the tube was centrifuged for $2 \mathrm{~min}$ at 1,200 rpm and the supernatant has discarded. The washing procedure of islets was repeated again and the remainding sample was transferred to a petri dish (16). The islets were separated by handpicking under a stereomicroscope (Euromex Microscopen BV, Arnhem, The Netherlands) and were cultured overnight in RPMI-1640 medium (Gibco, Invitrogen Life Technologies Carlsbad, CA, USA), supplemented with $10 \%$ fetal bovine serum, $100 \mathrm{U} / \mathrm{ml}$ penicillin, $100 \mathrm{U} / \mathrm{ml}$ streptomycin, $5 \mathrm{mmol} / 1$ D-glucose and was gassed with $95 \% \mathrm{O}_{2}-5 \% \mathrm{CO}_{2}$ atmosphere. Subsequently, the pancreatic islets were divided into 6 groups, including 3 control and 3 treatment groups: Control group 1: Incubated for $24 \mathrm{~h}$ in RPMI-1640 containing $5 \mathrm{mmol} / 1$ glucose (Sigma); control group 2: Incubated for $48 \mathrm{~h}$ in RPMI-1640 containing $5 \mathrm{mmol} / 1$ glucose; and control group 3: Incubated for $24 \mathrm{~h}$ in RPMI-1640 containing $25 \mathrm{mmol} / \mathrm{l}$ glucose; and treatment group 1: Incubated for $24 \mathrm{~h}$ in RPMI-1640 containing $5 \mathrm{mmol} / \mathrm{l}$ glucose and $15 \mu \mathrm{mol} / 1$ metformin; treatment group 2: Incubated for $48 \mathrm{~h}$ in RPMI-1640 containing $5 \mathrm{mmol} / 1$ glucose and $15 \mu \mathrm{mol} / 1$ metformin; and treatment group 3: Incubated for $24 \mathrm{~h}$ in RPMI-1640 containing $25 \mathrm{mmol} / \mathrm{l}$ glucose and $15 \mu \mathrm{mol} / 1$ metformin.

Insulin secretion measurement. Islet function was determined by monitoring insulin release following a static incubation glucose challenge assay. Function was determined by exposing the islets to glucose and metformin for different concentrations of glucose and for different periods, and determining how much insulin was secreted in response.

After in vitro treatment, 5 sets of 4 islets were incubated in HBSS containing 5 or $25 \mathrm{mmol} / 1$ glucose at $37^{\circ} \mathrm{C}$ for $1 \mathrm{~h}$. At the end of the incubation period, the supernatant was collected and frozen at $-20^{\circ} \mathrm{C}$ for later insulin radioimmunoassay (Bio-Rad, Hercules, CA, USA) using a mouse insulin standard (17).

Quantitative polymerase chain reaction $(q P C R)$. Total RNA was extracted from mouse pancreatic islets using the RNeasy plus mini kit (Qiagen, Hilden, Germany). RNA concentration was measured using a NanoDrop (Thermo Fisher Scientific, Inc., Wilmington, DE, USA). RNA (200 ng) was used to generate cDNA using the RevertAid First Strand cDNA Synthesis kit (Fermentas, Thermo Fisher Scientific) and amplified by qPCR using a QuantiTect SYBR-Green kit (Qiagen), the ABI StepOnePlus qPCR instrument and software (Applied Biosystems, Foster City, CA, USA). Primer sequences used are provided in Table I. All the quantifications were performed with mouse $\beta$-actin as an internal standard. The PCR was performed for 40 cycles at $95^{\circ} \mathrm{C}$ for $15 \mathrm{sec}, 60^{\circ} \mathrm{C}$ for $30 \mathrm{sec}$ and $72^{\circ} \mathrm{C}$ for $30 \mathrm{sec}(16,17)$.

Islet viability. Islet cell viability was tested by a colorimetric assay that detected the conversion of MTT (Sigma) into the formazan by the mitochondrial enzyme succinate dehydrogenase in viable cells $(18,19)$. After in vitro treatment, islets dissociated into single cells by incubation in HBSS containing $0.25 \mathrm{mg} / \mathrm{ml}$ trypsin for $10 \mathrm{~min}$ at $37^{\circ} \mathrm{C}$ with gentle agitation and were resuspended in RPMI-1640. Islet cells were cultured in a 96-well plate supplemented with $0.5 \mathrm{mg} / \mathrm{ml} \mathrm{MTT}$. After 
$4 \mathrm{~h}$ incubation, the insoluble formazan crystals within islet cells were extracted by dimethyl sulfoxide and absorbance was measured by a microplate reader (Bio-Rad) at a wavelength of $\lambda_{\text {test }}=570 \mathrm{~nm}$ and $\lambda_{\text {reference }}=650 \mathrm{~nm}$.

Statistical analysis. Data were expressed by SPSS software (SPSS, Inc., Chicago, IL, USA) as mean \pm standard error of the mean. One-way analysis of variance was used for comparison of the data from different groups, followed by the Tukey's test. $\mathrm{P}<0.05$ was considered to indicate a statistically significant difference.

\section{Results}

In vitro islet function. The rate of insulin secretion (ng/ml/60 min/islet) from isolated islets in $5 \mathrm{mmol} / \mathrm{l}$ glucose in the $48 \mathrm{~h}$ treatment group (glucose plus metformin) increased significantly compared with that of the 24 h treatment group $(\mathrm{P}<0.05)$. The differences between the control groups compared with the treatment groups were not significant (Fig. 1).

To determine the effect of different concentrations of glucose on insulin secretion in the glucose alone and glucose plus metformin groups, insulin secretion was examined at different extracellular glucose concentrations. Treated mice islets were incubated for $60 \mathrm{~min}$ in the presence of 5 or $25 \mathrm{mmol} / \mathrm{l}$ glucose, and the results demonstrated that in the glucose compared with the glucose and metformin group, insulin secretion increased but this difference was not significant. Data demonstrated that insulin secretion increased with the increase of glucose concentration (Fig. 2).

$q P C R$. The $P d x-1$ and insulin gene expression was analyzed by qPCR to demonstrate whether metformin has a significant effect on $\beta$-cell function during different time exposures to glucose or glucose plus metformin.

The $P d x-1$ gene expression in the glucose plus metformin group 1 decreased compared with that of the control group 1, and $P d x-1$ gene expression in glucose plus metformin group 2 decreased significantly compared with the control group 2 $(\mathrm{P}<0.05)$, as well as during different time exposures to glucose plus metformin group 2 (48 h) compared with the glucose plus metformin group 1 (24 h) (Fig. 3).

To investigate the effect of metformin on insulin gene expression during different time exposures of metformin and glucose, the same experiment was performed. The expression of the insulin gene in treatment group 1 increased compared with that of control group 1, and in glucose plus metformin group 2 there was a 2 -fold increase in insulin gene expression compared with that of control group 2 . The expression of the insulin gene in the glucose plus metformin group 2 increased compared with that of glucose plus metformin group 1 (Fig. 4).

Islet viability. Incubations of pancreatic islet cells with MTT demonstrated that reduction of this compound to formazan differed in islet cells of different treatment groups. Formazan formation was increased in treatment group $3(25 \mathrm{mmol} / \mathrm{l}$ glucose and metformin) by $\sim 40 \%$ compared with the islets of treatment groups 1 and $2(\mathrm{P}<0.05)$ (Fig. 5).

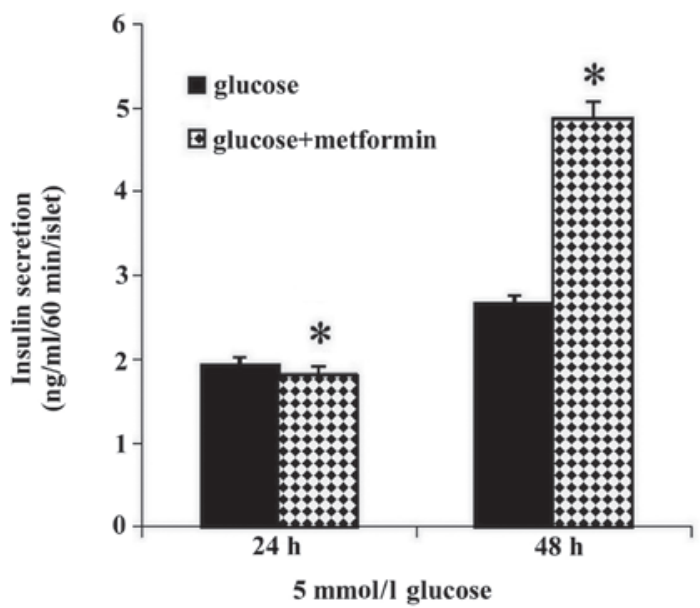

Figure 1. Effect of different exposure times (24 and 48 h) of glucose alone and glucose plus metformin on insulin secretion at a $5 \mathrm{mmol} / \mathrm{l}$ glucose concentration. Insulin release in the $48 \mathrm{~h}$ glucose plus metformin group increased significantly compared with that of $24 \mathrm{~h}$ glucose plus metformin group $\left({ }^{*} \mathrm{P}<0.05\right)$. Results are expressed as mean \pm standard error of the mean.

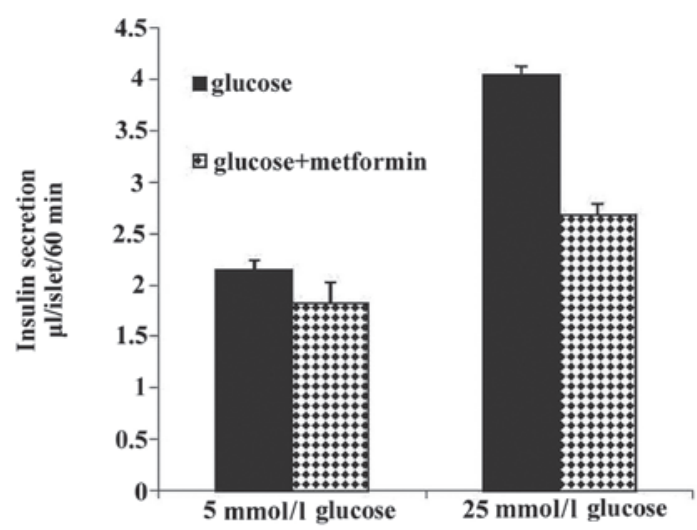

Figure 2. Effect of different glucose concentrations (5 or $25 \mathrm{mmol} / \mathrm{l}$ ) on insulin secretion in the glucose and glucose plus metformin groups. In the glucose group compared with the glucose plus metformin group, insulin secretion was increased but this difference was not significant. The increase of glucose concentration $(25 \mathrm{mmol} / \mathrm{l})$ causing insulin secretion was increased compared with that of glucose $5 \mathrm{mmol} / \mathrm{l}$.

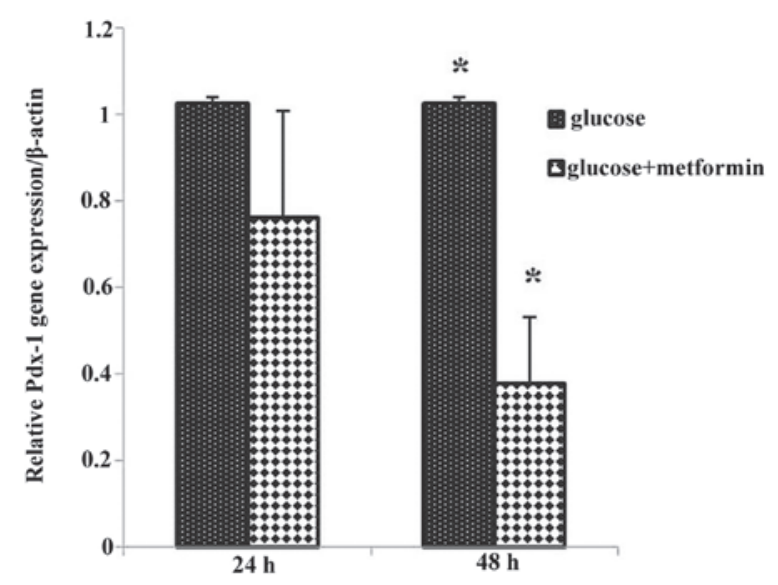

Figure 3. $P d x-1$ gene expression in glucose plus metformin group 1 decreased compared with that of the control group 1. $P d x-1$ gene expression in glucose plus metformin group 2 significantly decreased compared with that of control group $2\left({ }^{*} \mathrm{P}<0.05\right)$. The expression of the $P d x-1$ gene in treatment group 2 decreased compared with that of treatment group $1 .{ }^{*} \mathrm{P}<0.05$. 


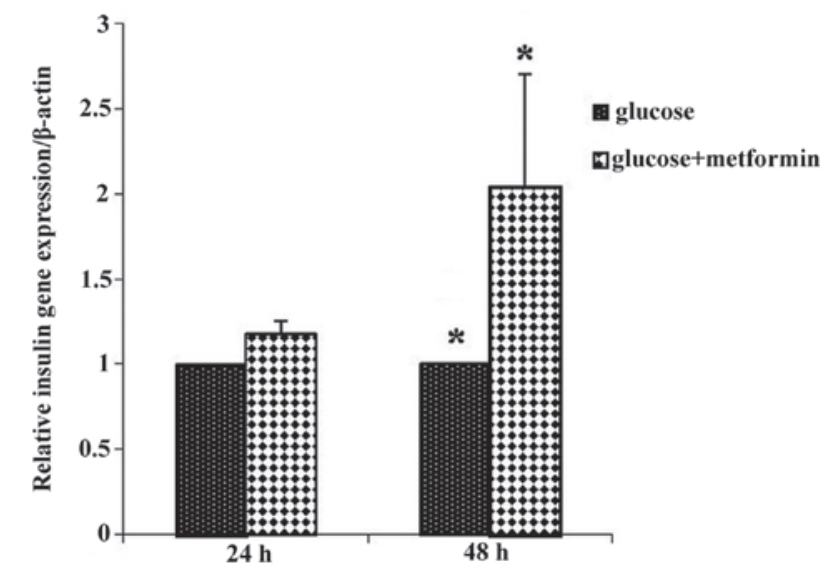

Figure 4. Insulin gene expression in the glucose plus metformin group 1 increased compared with the control group $1\left({ }^{*} \mathrm{P}<0.05\right)$, and in glucose plus metformin group 2, there was a 2-fold increase in insulin gene expression compared with that of control group 2. Insulin gene expression in the glucose plus metformin group 2 increased compared with that of glucose plus metformin group 1.

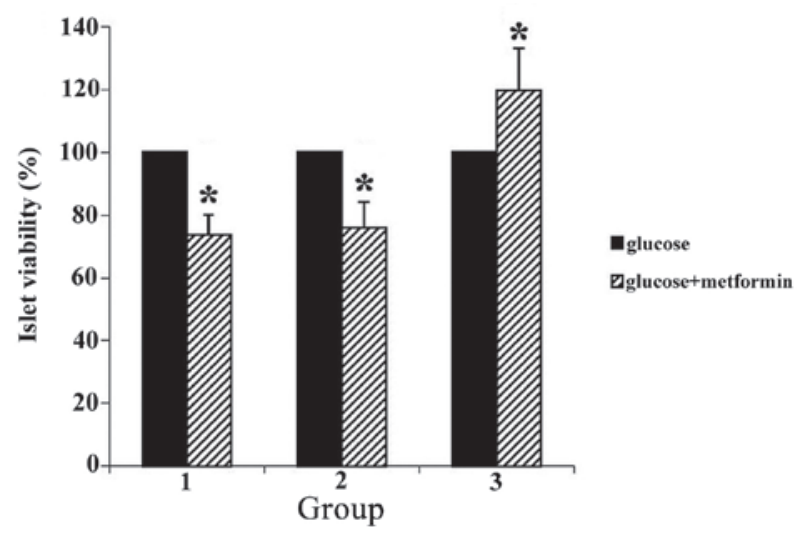

Figure 5. Percentage of islet cell viability was increased in treatment group 3 by $\sim 40 \%$ compared with the islet cells of treatment groups 1 and $2\left({ }^{*} \mathrm{P}<0.05\right)$.

\section{Discussion}

In the present study, metformin and glucose had evident effects on $\beta$-cell genes expression, islet function and viability in mouse pancreas.

Previous studies indicated that in type II diabetes islets secrete less insulin in response to glucose compared wtih that of the control group. This deficiency is characterized by loss of first-phase insulin secretion $(20,21)$, and the present study showed that insulin release in the metformin plus glucose group increased in a time-dependent manner. The data demonstrated that insulin secretion increased with the increase of glucose concentration, consistent with the study by Marchetti et al (22), which showed that metformin incubation restored insulin release. This effect was associated with replenishment of islet insulin storage (as indicated by the total insulin content and mature insulin granules). Leclerc et al (23) demonstrated that in the control group, increases in glucose concentration activate insulin release, which is consistent with the present study. However, we demonstrated that in the metformin plus glucose group the increases in glucose concentration activate insulin release, but Leclerc et al (23) showed that increases in glucose concentration in the metformin-treated group inhibits insulin secretion.

The increase in insulin release could be due to a more efficient insulin synthesis. The present study demonstrated that exposure of the islets in the metformin and glucose group caused a 2-fold increase in insulin mRNA in a time-dependent manner. A previous study by Marchetti et al (22) indicated that in type II diabetes islets insulin mRNA was markedly lower than that of the control islets and increased significantly following exposure to metformin (24). The present findings showed a significant decrease in $P d x-1$ mRNA during time exposure to metformin plus glucose. This data is consistent with a previous study by Richardson et al (25), which showed that metformin can stimulate $\mathrm{Pdx}-1$ post-transcriptional modification, leading to immobilization of the $\mathrm{Pdx}-1$ protein into the nucleus $>24 \mathrm{~h}$ and there was no $P d x-1$ upregulation in the level of Pdx-1 promoter activity in the electrophoresis mobility shift assay. They demonstrated that metformin stimulates $\mathrm{Pdx}-1$ at the protein production levels by western blot analysis and not at the $P d x-1$ gene expression level. Therefore, a significant decrease in mRNA of $P d x-1$ in the metformin plus glucose group in a time-dependent manner may be due to the increase in translation of $P d x-1$ mRNA, and therefore, the increase in the $P d x-1$ transcription factor causes transcription of the insulin gene, and therefore the insulin mRNA level increases.

In type II diabetes, a deficiency of $\beta$-cell survival exists. Previously, Butler et al (4) examined autoptic pancreatic tissue, reported a several-fold increase in the frequency of $\beta$-cell apoptosis. Our present study showed that metformin plus $25 \mathrm{mmol} / \mathrm{l}$ glucose caused an $\sim 40 \%$ increase in islet cell viability. This is consistent with the study by Marchetti et al (22), which found that metformin had an antiapoptotic effect, paralleled by a reduction of caspase- 3 and -8 activities.

By contrast, Kefas et al (26) showed that metformin impairs glucose responsivity and enhances susceptibility to apoptosis.

The differences between the results may be due to variation in culture processes and experimental models, the dose of metformin, as differences are species specific, and the duration of metformin and glucose presence.

In conclusion, the present study indicates that metformin has a profound effect on insulin release, transcriptional regulation in pancreatic islets and islet cell viability, and these effects are dependent on the presence of glucose. These data indicate that metformin has direct effects on islet function and suggests that this widely prescribed antidiabetic drug may play a previously unrecognized role in the direct regulation of pancreatic $\beta$-cell function. Further studies are required to fully delineate the cell signaling mechanisms regulating these events.

\section{Acknowledgements}

The present study was financially supported by grant no. CMRC-6 from the Vice-Chancellor for Research Affairs of Ahvaz Jundishapur University of Medical Sciences. 


\section{References}

1. American Diabetes Association: Diagnosis and classification of diabetes mellitus. Diabetes Care 29 (Suppl 1): S43-S48, 2006.

2. Szkudelski T,Zywert A and Szkudelska K: Metabolic disturbances and defects in insulin secretion in rats with streptozotocin-nicotinamide-induced diabetes. Physiol Res 62: 663-670, 2013

3. Wang H, Kouri G and Wollheim CB: ER stress and SREBP-1 activation are implicated in $\beta$-cell glucolipotoxicity. J Cell Sci 118: 3905-3915, 2005

4. Butler AE, Janson J, Bonner-Weir S, Ritzel R, Rizza RA and Butler PC: $\beta$-cell deficit and increased $\beta$-cell apoptosis in humans with type 2 diabetes. Diabetes 52: 102-110, 2003.

5. Weir GC, Laybutt DR, Kaneto H, Bonner-Weir S and Sharma A: Beta-cell adaptation and decompensation during the progression of diabetes. Diabetes 50 (Suppl 1): S154-S159, 2001.

6. Viollet B, Guigas B, Sanz Garcia N, Leclerc J, Foretz M and Andreelli F: Cellular and molecular mechanisms of metformin: An overview. Clin Sci (Lond) 122: 253-270, 2012.

7. Gunton JE, Delhanty PJ, Takahashi S and Baxter RC: Metformin rapidly increases insulin receptor activation in human liver and signals preferentially through insulin-receptor substrate-2. J Clin Endocrinol Metab 88: 1323-1332, 2003.

8. Cusi K, Consoli A and DeFronzo RA: Metabolic effects of metformin on glucose and lactate metabolism in noninsulin-dependent diabetes mellitus. J Clin Endocrinol Metab 81: 4059-4067, 1996.

9. Hundal RS, Krssak M, Dufour S, Laurent D, Lebon V, Chandramouli V, Inzucchi SE, Schumann WC, Petersen KF, Landau BR, et al: Mechanism by which metformin reduces glucose production in type 2 diabetes. Diabetes 49: 2063-2069, 2000.

10. Natali A and Ferrannini E: Effects of metformin and thiazolidinediones on suppression of hepatic glucose production and stimulation of glucose uptake in type 2 diabetes: A systematic review. Diabetologia 49: 434-441, 2006.

11. Gregorio F, Filipponi P, Ambrosi F, Cristallini S, Marchetti P, Calafiore R, Navalesi R and Brunetti P: Metformin potentiates $\mathrm{B}$-cell response to high glucose: An in vitro study on isolated perfused pancreas from normal rats. Diabete Metab 15: 111-117, 1989.

12. Marchetti P, Scharp DW, Giannarelli R, Benzi L, Cicchetti P, Ciccarone AM, Lacy PE and Navalesi R: Metformin potentiates glucose-stimulated insulin secretion. Diabetes Care 19: 781-782, 1996.

13. Lacy PE, Kostianovsky M and Louis S: Method for the isolation of intact islets of Langerhans from the rat pancreas. Diabetes 16: 35-39, 1967.

14. Perfetti R, Zhou J, Doyle ME and Egan JM: Glucagon-like peptide-1 induces cell proliferation and pancreatic-duodenum homeobox-1 expression and increases endocrine cell mass in the pancreas of old, glucose-intolerant rats. Endocrinology 141 4600-4605, 2000

15. Panza JL, Wagner WR, Rilo HL, Rao RH, Beckman EJ and Russell AJ: Treatment of rat pancreatic islets with reactive PEG. Biomaterials 21: 1155-1164, 2000.
16. Marselli L, Dotta F, Piro S, Santangelo C, Masini M, Lupi R, Realacci M, del Guerra S, Mosca F, Boggi U, et al: Th2 cytokines have a partial, direct protective effect on the function and survival of isolated human islets exposed to combined proinflammatory and Th1 cytokines. J Clin Endocrinol Metab 86: 4974-4978, 2001.

17. Lupi R, Del Guerra S, Marselli L, Bugliani M, Boggi U, Mosca F, Marchetti P and Del Prato S: Rosiglitazone prevents the impairment of human islet function induced by fatty acids: Evidence for a role of PPARgamma2 in the modulation of insulin secretion. Am J Physiol Endocrinol Metab 286: E560-E567, 2004.

18. Janjic D and Wollheim CB: Islet cell metabolism is reflected by the MTT (tetrazolium) colorimetric assay. Diabetologia 35: 482-485, 1992

19. Wang ZQ, Lu FE, Leng SH, Fang XS, Chen G, Wang ZS, Dong LP and Yan ZQ: Facilitating effects of berberine on rat pancreatic islets through modulating hepatic nuclear factor 4 alpha expression and glucokinase activity. World J Gastroenterol 14: 6004-6011, 2008.

20. Fernandez-Alvarez J, Conget I, Rasschaert J, Sener A, Gomis R and Malaisse WJ: Enzymatic, metabolic and secretory patterns in human islets of type 2 (non-insulin-dependent) diabetic patients. Diabetologia 37: 177-181, 1994.

21. Deng S, Vatamaniuk M, Huang X, Doliba N, Lian M-M, Frank A, Velidedeoglu E, Desai NM, Koeberlein B, Wolf B, et al: Structural and functional abnormalities in the islets isolated from type 2 diabetic subjects. Diabetes 53: 624-632, 2004

22. Marchetti P, Del Guerra S, Marselli L, Lupi R, Masini M, Pollera M, Bugliani M, Boggi U, Vistoli F, Mosca F, et al: Pancreatic islets from type 2 diabetic patients have functional defects and increased apoptosis that are ameliorated by metformin. J Clin Endocrinol Metab 89: 5535-5541, 2004.

23. Leclerc I, Woltersdorf WW, da Silva Xavier G, Rowe RL, Cross SE, Korbutt GS, Rajotte RV, Smith R and Rutter GA: Metformin, but not leptin, regulates AMP-activated protein kinase in pancreatic islets: Impact on glucose-stimulated insulin secretion. Am J Physiol Endocrinol Metab 286: E1023-E1031, 2004.

24. Lin J-M, Fabregat ME, Gomis R and Bergsten P: Pulsatile insulin release from islets isolated from three subjects with type 2 diabetes. Diabetes 51: 988-993, 2002.

25. Richardson H, Campbell SC, Smith SA and Macfarlane WM: Effects of rosiglitazone and metformin on pancreatic beta cell gene expression. Diabetologia 49: 685-696, 2006.

26. Kefas BA, Cai Y, Kerckhofs K, Ling Z, Martens G, Heimberg H, Pipeleers D and Van de Casteele M: Metformin-induced stimulation of AMP-activated protein kinase in $\beta$-cells impairs their glucose responsiveness and can lead to apoptosis. Biochem Pharmacol 68: 409-416, 2004. 